\title{
Ehlers-Danlos Syndrome Type VIIC: A Mexican Case Report
}

\author{
Ana Rosa Rincón-Sánchez ${ }^{\mathrm{a}} \quad$ Irma Elia Arce $^{\mathrm{e}}$ \\ Enrique Alejandro Tostado-Rabago ${ }^{f}$ Alberto Vargas ${ }^{g}$ \\ Luis Alfredo Padilla-Gómez ${ }^{\text {h }}$ Alejandro Bolaños ${ }^{i}$ \\ Selenne Barrios-Guyot ${ }^{j} \quad$ Víctor Manuel Anguiano-Alvarez $^{b}$ \\ Víctor Chistian Ledezma-Rodríguez ${ }^{\mathrm{b}}$ \\ María Cristina Islas-Carbajal ${ }^{c}$ Ana María Rivas-Estilla' \\ Alfredo Feria-Velasco ${ }^{d}$ Nory Omayra Dávalos ${ }^{\text {b, } k}$ \\ Institutos de ${ }^{\mathrm{a} E n f e r m e d a d e s ~ C r o ́ n i c o ~ D e g e n e r a t i v a s ~ y ~}{ }^{\mathrm{b}}$ Genética Humana, y \\ 'Unidad de Investigación Cardiovascular, Centro Universitario de Ciencias de la

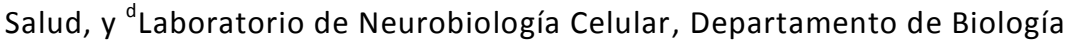 \\ Molecular CUCBA, Universidad de Guadalajara, Guadalajara, 'Neonatología, \\ ${ }^{f}$ Cirugía-Pediátrica, ${ }^{\mathrm{g}}$ Oftalmología, ${ }^{\mathrm{h}}$ Neuropediatría, 'Ortopedia y \\ Traumatología, 'Cardiopediatría, y ${ }^{\mathrm{k}}$ Genética, Hospital Regional ‘Dr. Valentín \\ Gómez Farias' ISSSTE, Zapopan, y 'Departamento de Bioquímica y Biología \\ Molecular, Facultad de Medicina, Universidad Autónoma de Nuevo León, \\ Monterrey, México
}

\section{Key Words}

Ehlers-Danlos syndrome - Human dermatosparaxis - Elastic connective tissue . ADAMTS2 gene

\begin{abstract}
Ehlers-Danlos syndrome (EDS) is a heterogeneous group of heritable connective tissue disorders whose primary clinical features include soft and extensible skin, articular hypermobility and tissue fragility. EDS type VIIC or 'human dermatosparaxis' is an autosomal recessive disease characterized by severe skin fragility and sagging redundant skin (major criteria) with a soft, doughy texture, easy bruising, premature rupture of fetal membranes and large hernias (minor criteria). Dermatosparaxis (meaning 'tearing of skin'), which has been described in several non-human species, is a disorder of the connective tissue resulting from a deficiency of the enzyme that cleaves the registration peptide off the $\mathrm{N}$-terminal end of collagen after it has been secreted from fibroblasts. We describe a Mexican case from consanguineous parents with all the phenotypical characteristics previously described, plus skeletal abnormalities.
\end{abstract}




\section{Introduction}

Ehlers-Danlos syndrome (EDS) is an inherited disorder of the elastic connective tissue characterized by hyperelasticity of the skin, hypermobility of the joints due to extremely lax ligaments and tendons, and poor wound healing. The first classical description of the syndrome was attributed to Tschernogubow, who described it in 1891 [1]. EDS was first reported by Edvard Ehlers (1899) and Hernri-Alexandre Danlos (1908), but it was not until 1936 that Frederick Parkes Weber suggested that the disorder be named Ehlers-Danlos syndrome [2]. The estimated overall prevalence for all groups of EDS is 1/5000, with no racial predisposition; only 7 cases of EDS type VIIC (EDSVIIC) have been reported in the literature [3, 4]. EDS inheritance patterns depend on the type of EDS; most forms are transmitted through an autosomal dominant pattern, and a minority are inherited in an autosomal recessive pattern or X-linked patterns of inheritance. In addition, it can also be associated with an individual (de novo or 'sporadic') DNA mutation.

The categorization of EDS began in the late 1960s. An initial classification defined 10 different types, but the most recent classification recognizes 6 groups based on clinical, genetic and biochemical characteristics. The 6 major groups of EDS according to Villefranche classification are: (1) Classical (EDS types I and II); (2) Hypermobility (type III); (3) Vascular (type IV); (4) Kyphoscoliosis (type VI); (5) Arthrochalasia (type VIIA and VIIB), and (6) Dermatosparaxis (type VIIC). Other variants includes EDS Xlinked (type V) and periodontal EDS (type VIII) [2, 5-7].

EDS Dermatosparaxis type, or EDSVIIC (MIM 225410), and the related disease in cattle dermatosparaxis, are rare, recessively inherited connective tissue disorders characterized by extreme skin fragility. This is caused by deficiency of procollagen I Nterminal peptidase, by homozygosity or compound heterozygosity of mutant alleles [713]. Analysis of sequences has demonstrated that mutations in the pNP gene lead to the recessively inherited human disorder EDSVIIC. Analysis of sequences has also shown that pNP protein belongs to the recently described ADAMTS (a disintegrin and metalloproteinase with thrombospondin motifs) family of metalloproteinases and has led to the designation of pNPI as ADAMTS2 $[1,14]$.

ADAMTS2 is a gene that produces an enzyme which is responsible for processing several types of procollagen proteins. This enzyme clips a short chain of amino acids off one end of the procollagen. This clipping step is necessary for collagen molecules to function normally and assemble into fibrils outside cells. The ADAMTS2 gene is located on the long (q) arm of chromosome 5 at the end (terminus) of the arm, from base pair $178,473,473$ to base pair $178,704,934[1,14]$.

Only 7 cases of EDSVIIC have been reported in the literature (table 1) $[9,10,12,15$, 16]; the last 2 cases were recently published by Pasch et al. in 2000 [17] and Bar-Yosef et al. in 2008 [18].

In the present report, we describe the eighth case of an EDSVIIC patient who showed skin fragility, characteristic physical changes and skeletal anomalies not previously reported. We documented the physical changes during the first year of life of our patient. 


\section{Case Report}

The propositus was born at 28 weeks' gestation to a G4 P3 36-year-old mother and a 39-year-old father (consanguineous parents) (fig. 1). The mother had premature rupture of membranes at 26 weeks of gestation and was hospitalized for 2 weeks. A Cesarean section was performed because of oligohydramnios diagnosed by ultrasound. Physical examination showed a male fetus with a weight of $1,350 \mathrm{~g}$, a length of $41 \mathrm{~cm}$ and an occipitofrontal circumference (OFC) of $40 \mathrm{~cm}$, with all percentiles below normal and an Apgar score of 7-8. He had a wide-open anterior fontanel communicating with the posterior fontanel, measuring $5 \times 15 \mathrm{~cm}$. His facial appearance was unusual with hirsutism of the forehead, protruding eyes with swollen eye lids and blue sclera. Intra-oral examination showed a high palate, severe gingival hyperplasia and micrognathia (fig. 2). A large umbilical hernia was present since birth (5 cm, fig. 3). The limbs were short with short, stubby fingers and redundant skin (cutis laxa). Laboratory examinations including routine blood and urine tests, lipid and thyroid profiles and metabolic screening yielded normal or negative results. In the following months, psychomotor retardation was noted. He had a social smile at 4 months, rolled over at 8 months and was verbalizing consonant sounds at 14 months of age. At 15 months, his umbilical hernia was repaired without complications. At 4 months, gastroesophageal reflux was diagnosed. At 11 months, ultrasound examination of the bladder and a voiding cystourethrogram were normal. Skeletal X-rays revealed spinal abnormalities such as: failure of anterior fusion of the cervical and thoracic vertebrae (D1-D8), and a lateral projection revealing a small L1 vertebral body and showing anterior discontinuity with a U-shaped indentation and short phalanges (fig. 3d, fig. 4a, c). Echocardiogram and cranial ultrasound were normal. Cranial MRI showed only slight hypoplasia of the corpus callosum, and cortical and subcortical atrophy. When he was 15 months old, somatometry continued to be below the 3rd percentile, with the following measurements: weight 5,200 g, length $60 \mathrm{~cm}$ and OFC $41.5 \mathrm{~cm}$. The patient still had peculiar facies, a large fontanel, psychomotor developmental delay and late eruption of teeth. A second umbilical hernia surgery was performed. He presented some complications and died 3 days after surgery when he was 2 years, 7 months old.

A skin and skeletal muscle biopsy from the right thigh were immediately fixed in phosphatebuffered $4 \%$ paraformaldehyde solution for $16 \mathrm{~h}$, washed, dehydrated in graded ethanol solutions and embedded in Paraplast. Three-micrometer-thick sections were obtained in a rotatory microtome and the sections were collected on glass slides to be stained with HE and Mallory's trichrome stains and examined under a light microscope (Leica; Germany). The skin biopsy showed no significant differences in the tissue elements of epidermis and epithelial dermal structures, while moderate disorganization of collagen bundles at the deep dermal portion and subcutaneous connective tissue was observed (fig. $5 a$ ). In the muscle biopsy, the muscle fibers in cross- and longitudinal sections appeared normal in structure and thickness, while a wide interfascicular space and thin connective tissue fibers were seen (fig. $5 \mathrm{~b}$ ).

\section{Clinical Manifestations}

These are the clinical features of EDSVIIC that confirmed his diagnosis during the first year of life: premature rupture of membranes; extreme skin fragility and easy bruising; doughy, sagging, redundant skin (especially facial); large fontanels; blue sclera; puffy eyelids, blepharochalasis; large umbilical hernia; short stature; short fingers and dwarfism. Joint hypermobility becomes more important with age. The oral findings comprised micrognathia, hypodontia, localized microdontia, discolored teeth, root dysplasia, severe gingival hyperplasia, and frontal open bite. The deciduous dentition showed abnormal morphology of the molars.

\section{Discussion}

EDSVIIC (MIM 225410) is a distinct connective tissue disorder characterized by extreme skin fragility and laxity, redundant skin, blue sclera, increased bruisability, micrognathia, umbilical or inguinal hernia, numerous palmar creases and growth retardation (table 1). As can be observed in table 1, all major diagnostic criteria were present in the 8 reported cases. The minor diagnostic criteria were evident in the physical exam and clinical history. Unfortunately, the death of our patient happened 
due to a surgical complication which also corresponded to one of the minor diagnostic criteria [7].

Related to molecular pathogenesis EDS, the Dermatosparaxis type is caused by mutations in the ADAMTS2 gene. Several mutations in the ADAMTS2 gene have been identified in people with this syndrome. These mutations greatly reduce the production of the enzyme made by the ADAMTS2 gene. As a result, collagen fibrils are not assembled properly; they appear ribbon-like and disorganized under the microscope. Cross-links, or chemical interactions, between collagen fibrils are also affected. These defects weaken connective tissue (the tissue that binds and supports the body's muscles, ligaments, organs and skin), which causes the signs and symptoms of the disorder.

The inheritable disorder results from a failure to process type I procollagen to mature collagen protein. A suspected clinical diagnosis can be confirmed by altered polymers seen as hieroglyphics in electron microscopy, accumulation of $\mathrm{p}-\mathrm{N}-\alpha 1$ and $\mathrm{p}-$ $\mathrm{N}-\alpha 2$ collagen type I in the dermis, and the absence of processing of the $\mathrm{p}-\mathrm{N}-\mathrm{I}$ polypeptides in fibroblast cultures. A skin and skeletal muscle biopsy was analyzed by light microscopy. The arrangement of collagen fibers and clinical manifestations confirmed the suspected clinical diagnosis (fig. 5) [19-21].

Patients affected with EDSVIIC have abnormal type-I collagen molecules. Gastrointestinal and skeletal abnormalities have not been described in the 7 cases previously reported. Our patient had presented gastroesophageal reflux since birth. Abnormally-shaped phalanges and irregular vertebral bodies were also detected. We suggest that these new findings could be part of the phenotype spectrum of EDSVIIC, and the parents' consanguinity suggests an autosomal recessive inheritance.

\section{Acknowledgement}

The authors greatly appreciate the support of the personnel at Hospital Regional del ISSSTE 'Dr. Valentín Gómez Farías', Guadalajara, Jalisco, for their invaluable technical help.

\section{Disclosure Statement}

The authors declare no conflict of interest. 
Table 1. Clinical summary of reported EDSVIIC

\begin{tabular}{|c|c|c|c|c|c|c|c|c|c|}
\hline & $\begin{array}{l}\text { Wertelecki } \\
\text { et al. } \\
\text { [1992] } \\
\text { case } 1\end{array}$ & $\begin{array}{l}\text { Smith et al. } \\
{[1992] \text {, }} \\
\text { Petty, et al. } \\
\text { [1993] } \\
\text { case 2 }\end{array}$ & $\begin{array}{l}\text { Nusgens } \\
\text { et al. } \\
\text { [1992] } \\
\text { case 3 }\end{array}$ & $\begin{array}{l}\text { Readon et al. } \\
\text { [1995] } \\
\text { case } 4\end{array}$ & $\begin{array}{l}\text { Fujimoto et al. } \\
\text { [1997] } \\
\text { case } 5\end{array}$ & $\begin{array}{l}\text { Pasch et al. } \\
{[2000]} \\
\text { case } 6\end{array}$ & $\begin{array}{l}\text { Bar-Yosef et al. } \\
\text { [2008] } \\
\text { case } 7\end{array}$ & $\begin{array}{l}\text { Present } \\
\text { work } \\
\text { case } 8\end{array}$ & $\begin{array}{l}\text { Sum- } \\
\text { mary }\end{array}$ \\
\hline Sex & $\mathrm{F}$ & M & $\mathrm{F}$ & $\mathrm{F}$ & M & M & M & M & $\begin{array}{l}\text { M5/ } \\
\text { F3 }\end{array}$ \\
\hline Age, years & 2 & 2 & 2 & $1 \frac{1}{4}$ & $1 / 2$ & $11 / 4$ & & Newborn & \\
\hline Gestation, weeks & 28 & 35 & 29.5 & 32 & 30 & 38.4 & 33 & 28 & \\
\hline $\begin{array}{r}\text { Premature rupture } \\
\text { of membranes }\end{array}$ & + & + & + & + & + & - & + & + & $7 / 8$ \\
\hline Birth weight, g & 1,077 (50\%) & $2,345(25-50 \%)$ & $810(5 \%)$ & $2,200(75 \%)$ & $1,455(75 \%)$ & 3,900 & 1,950 & $1,320(<3 \%)$ & \\
\hline Length, cm & 37 & $45(25-50 \%)$ & $35(10 \%)$ & & $42(75 \%)$ & 49 & & $41(<3 \%)$ & \\
\hline$\overline{\mathrm{OFC}}, \mathrm{cm}$ & 26 & $31(25-50 \%)$ & & & $27.5(25-50 \%)$ & 36 & & 26 & \\
\hline Large fontanel & + & + & + & + & + & + & + & + & $8 / 8$ \\
\hline Edema of eyelids & + & + & + & + & + & + & + & + & $8 / 8$ \\
\hline Blue sclera & + & + & + & + & + & + & & + & $7 / 8$ \\
\hline Myopia & + & $?$ & $?$ & + & - & $?$ & & $?$ & $2 / 8$ \\
\hline Microgenitalia & + & + & + & + & + & + & & + & $7 / 8$ \\
\hline Umbilical hernia & + & + & + & + & + & + & + & + & $8 / 8$ \\
\hline $\begin{array}{l}\text { Short limbs and } \\
\text { fingers }\end{array}$ & + & + & + & + & + & + & + & + & $8 / 8$ \\
\hline Joint laxity & + & + & $?$ & + & - & + & + & + & $6 / 8$ \\
\hline Cutis laxa & + & + & + & + & + & + & + & + & $8 / 8$ \\
\hline Skin tear at birth & - & + & - & - & - & - & & + & $2 / 8$ \\
\hline $\begin{array}{l}\text { Postnatal skin } \\
\text { fragility }\end{array}$ & $+(7$ months $)$ & + (at birth) & $+(1$ year $)$ & $+(9$ months $)$ & $+(3$ months $)$ & + & + (at birth) & + & $8 / 8$ \\
\hline Easy bruisability & + & + & + & + & + & + & $?$ & $?$ & $6 / 8$ \\
\hline Short stature & + & + & $?$ & + & + & + & & + & $6 / 8$ \\
\hline Osteopenia & - & + & + & $?$ & - & $?$ & & $?$ & $2 / 8$ \\
\hline Wormian bones & $?$ & + & + & $?$ & - (at birth) & $?$ & $?$ & - (at birth) & $2 / 8$ \\
\hline $\begin{array}{c}\text { Other disease or } \\
\text { anomalies }\end{array}$ & $\begin{array}{l}\text { Hypothy- } \\
\text { roidism, } \\
\text { pneumo- } \\
\text { thorax }\end{array}$ & $\begin{array}{l}\text { Dental lamina } \\
\text { cyst, bicuspid } \\
\text { aortic valves, } \\
\text { pneumo- } \\
\text { thorax }\end{array}$ & & & $\begin{array}{l}\text { Hydronephrosis } \\
\text { at birth, } \\
\text { recurrent } \\
\text { pneumonia }\end{array}$ & $\begin{array}{l}\text { Respiratory } \\
\text { insufficiency at } \\
\text { the age of } 12 \\
\text { years due to a dia- } \\
\text { phragmatic hernia. } \\
\text { Afterwards he was } \\
\text { operated on for this }\end{array}$ & $\begin{array}{l}2 \text { temporal skull } \\
\text { fractures, bilateral } \\
\text { cryptorchidism, } \\
\text { cerebral hema- } \\
\text { toma, convulsions }\end{array}$ & $\begin{array}{l}\text { Skeletal, oral } \\
\text { and gastro- } \\
\text { intestinal } \\
\text { abnormalities }\end{array}$ & \\
\hline
\end{tabular}

Table was taken from Fujimoto et al., 1997 [12], with 5 cases. 


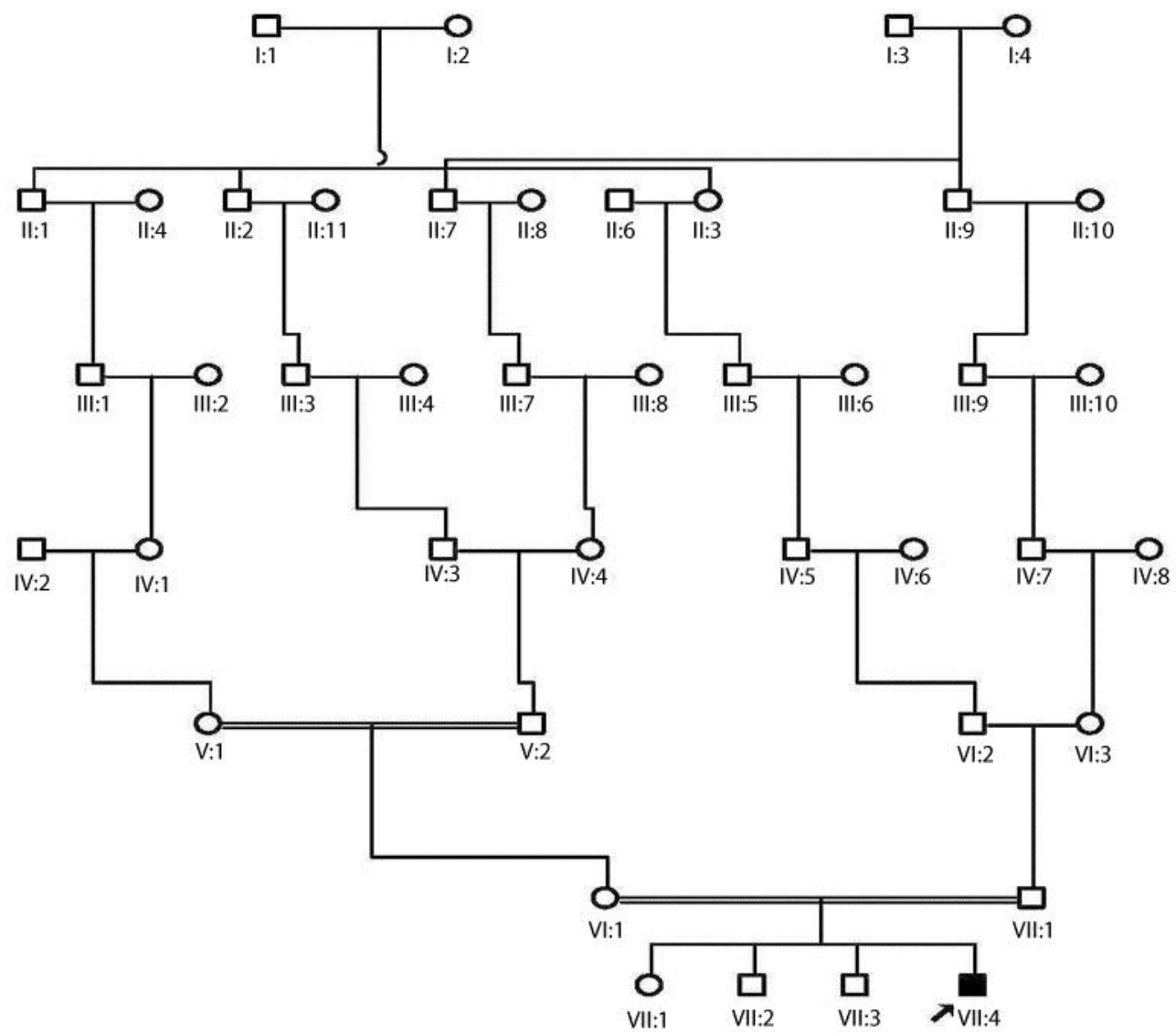

Fig. 1. Genealogical tree of the propositus. Genealogical tree showing that the mother of the index case was born of the marriage of her parents, who were relatives of the 5 th generation, descended from the paternal line of her great, great grandfathers who were brothers. In addition, the father of the propositus also descends from the same family as his wife, but through the sister of one of the great, great grandfathers who were brothers. It is for this reason that we included the relatives of 6 previous generations in order to demonstrate far consanguinity between the propositus' parents. During questioning, the parents of the propositus stated that none of their relatives showed any alteration in the skin, or at least it was not somewhat rare or notorious that they recall to have listened of their parents or grandfathers. Consanguinity was present in the 5th and 6th generation of this genealogical tree. Pedigree was made using Cyrillic software V.2. (Cyrillic Software, UK). 


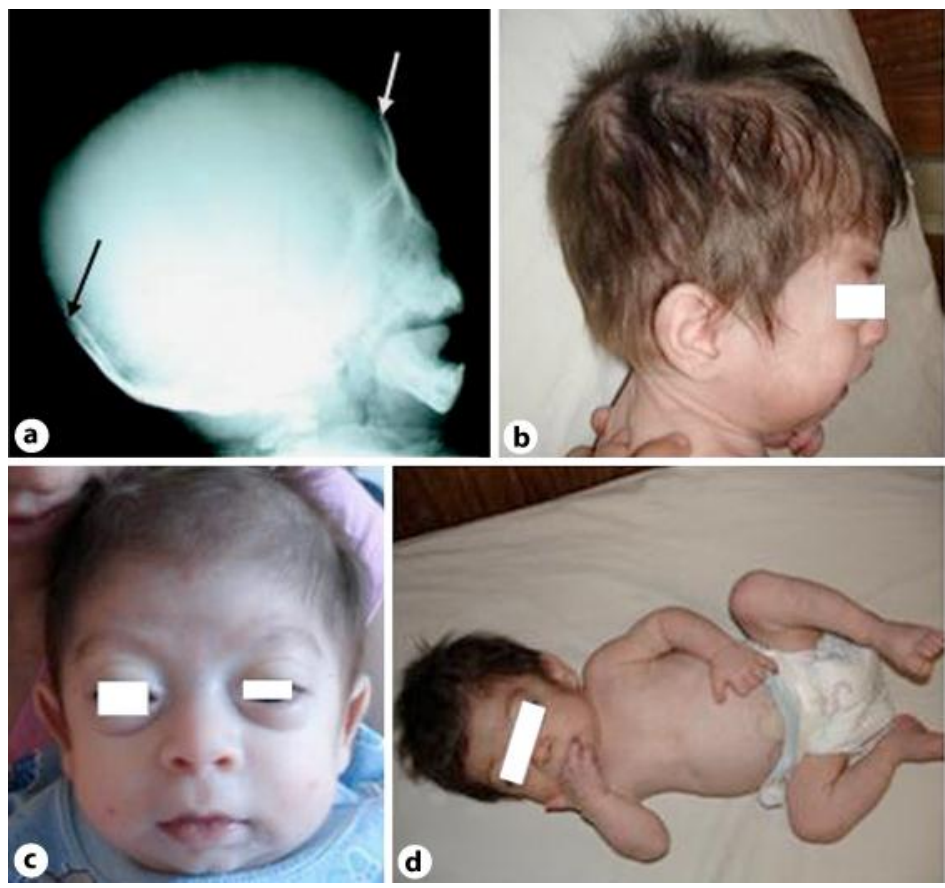

Fig. 2. a-d Clinical and X-ray photographs. a Lateral projection of the skull with large, open anterior fontanel. Arrows delimit fontanel amplitude. This X-ray was taken when the patient was 11 months old. b Redundant neck skin. c Swollen eyelids. d Short child, prominent abdomen, protruding umbilicus and redundant skin. 

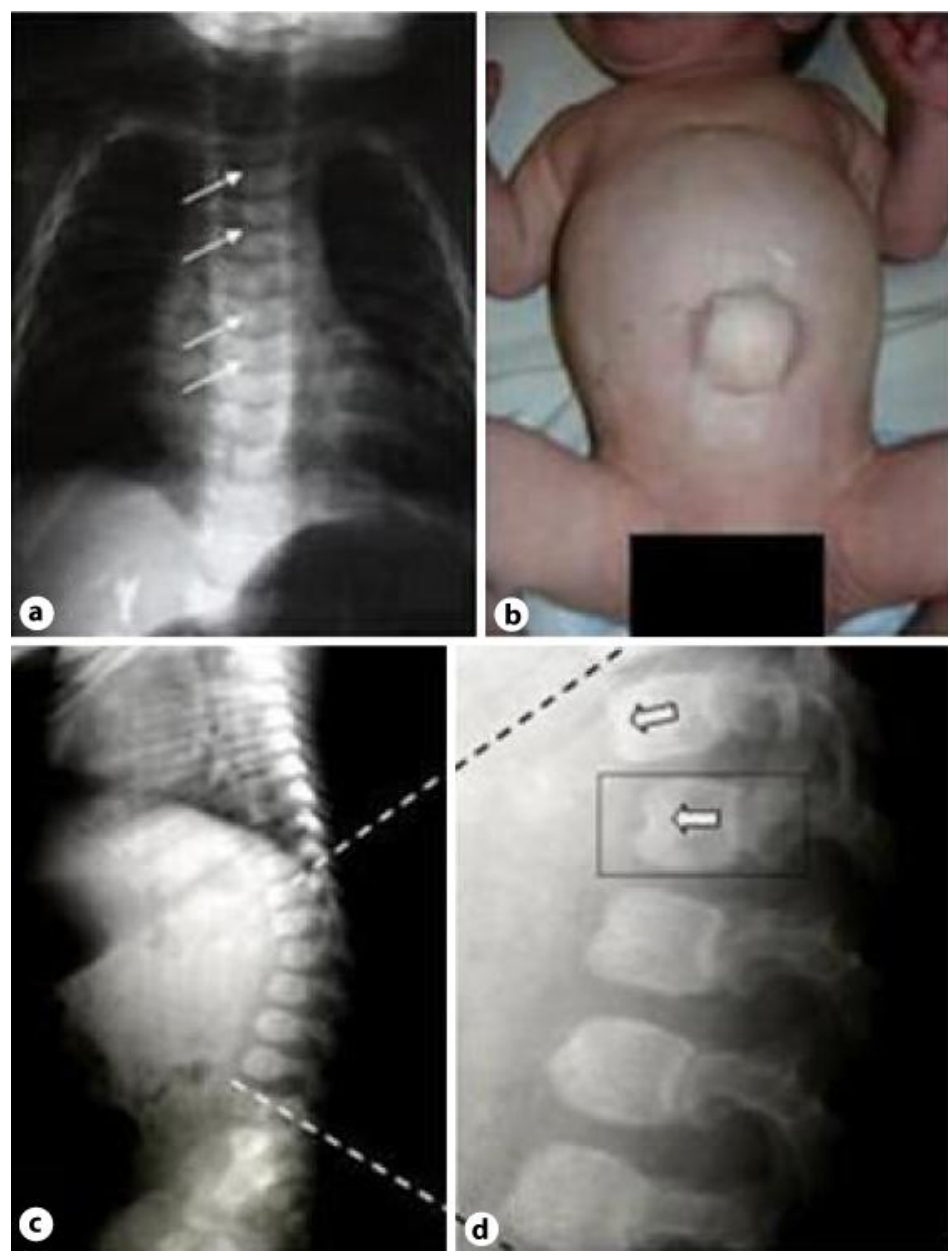

Fig. 3. a-d Clinical and skeletal X-ray photographs. a Anteroposterior X-ray of the spine, showing anterior failure of fusion of cervical and thoracic vertebrae (arrows) and dysmorphology of lumbosacral vertebral body. b Age 11 months; umbilical hernia. c Lateral X-ray of the spine. d Amplification of $\mathbf{c}$ showing small vertebral L1 body with anterior discontinuity by a U-shaped carved indentation. 

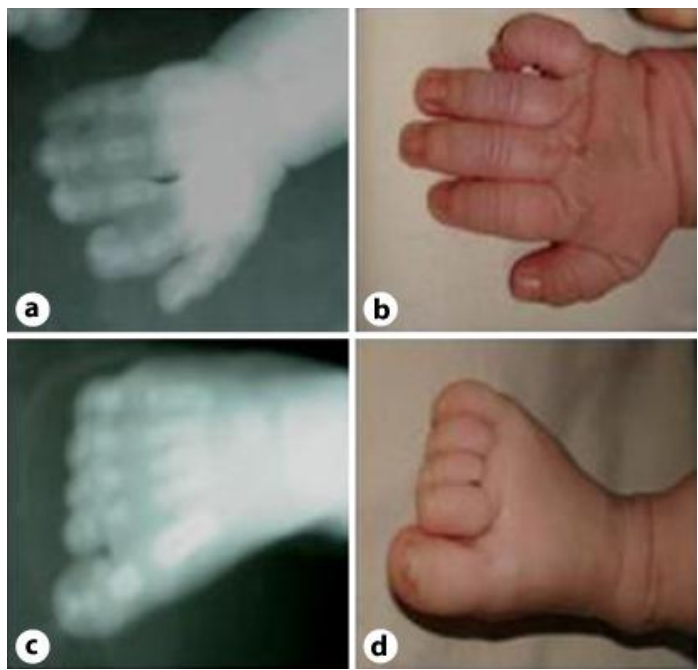

Fig. 4. a-d Clinical and X-ray photographs. a Anteroposterior (AP) X-ray of the hand. Note short, wide phalanges. b Hand with short stubby fingers and redundant skin. c AP X-ray of the foot. Note short, wide phalanges. $\mathbf{d}$ Foot with redundant ankle skin.
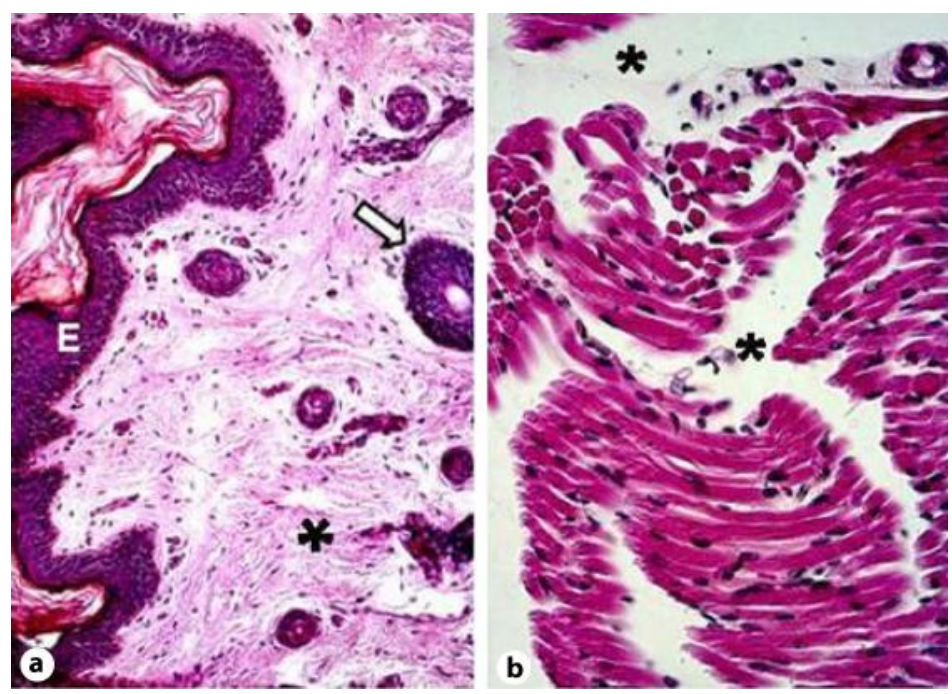

Fig. 5. a Light photomicrograph of the skin biopsy showing normal epidermal structure (E) and epithelial dermal elements (arrow). Bundles of collagen fibers appear moderately disorganized in the deep dermal portion (asterisk). HE stain $(\times 40)$. b Light photomicrograph of the skeletal muscle biopsy where cross- and longitudinal sectioned muscle fibers are observed showing normal structure. No abnormalities are seen except for the wide interfascicular spaces with thin connective tissue fibers (asterisks). HE stain $(\times 40)$. 


\section{References}

1 Callewaert B, Malfait F, Loeys B, De Paepe A: Ehlers-Danlos syndromes and Marfan syndrome. Best Pract Res Clin Rheumatol 2008;22:165-189.

-2 Lawrence EJ: The clinical presentation of Ehlers-Danlos syndrome. Adv Neonatal Care 2005;5:301-314.

3 Enerson OD: Elhers-Danlos Syndrome. Oslo, Norway: Who named it? (biography dictionary of medical eponyms) Elhers-Danlos syndrome. Available at: http://www.whonamedit.com/synd.cfm/2017.html. [Last accessed, June 2009]

4 Whitelaw SE: Ehlers-Danlos syndrome, classical type: case management. Pediatr Nurs 2003;29:423-426

5 Rand-Hendriksen S, Wekre LL, Paus B: Ehlers-Danlos syndrome - diagnosis and subclassification (in Norwegian). Tidsskr Nor Laegeforen 2006;126:1903-1907.

-6 Nicholls AC, Sher JL, Wright MJ, Oley C, Mueller RF, Pope FM: Clinical phenotypes and molecular characterisation of three patients with Ehlers-Danlos syndrome type VII. J Med Genet 2000;37:E33.

$\checkmark 7$ Beighton P, De Paepe A, et al: Ehlers-Danlos syndromes: revised nosology, Villefranche 1997. EhlersDanlos National Foundation (USA) and Ehlers-Danlos Support Group (UK). Am J Med Genet 1998;77:3137.

8 Steinmann B, Tuderman L, Peltonen L, Martin GR, McKusick VA, Prockop DJ: Evidence for a structural mutation of procollagen type I in a patient with the Ehlers-Danlos syndrome type VII. J Biol Chem 1980;255:8887-8893.

9 Nusgens BV, Verellen-Dumoulin C, Hermanns-Le T, De Paepe A, Nuytinck L, Pierard GE, Lapiere CM Evidence for a relationship between Ehlers-Danlos type VII $\mathrm{C}$ in humans and bovine dermatosparaxis. Nat Genet 1992;1:214-217.

10 Smith LT, Wertelecki W, Milstone LM, Petty EM, Seashore MR, Braverman IM, Jenkins TG, Byers PH: Human dermatosparaxis: a form of Ehlers-Danlos syndrome that results from failure to remove the amino-terminal propeptide of type I procollagen. Am J Hum Genet 1992;51:235-244.

11 Dalgleish R: The human type I collagen mutation database. Nucleic Acids Res 1997;25:181-187.

12 Fujimoto A, Wilcox WR, Cohn DH: Clinical, morphological, and biochemical phenotype of a new case of Ehlers-Danlos syndrome type VIIC. Am J Med Genet 1997;68:25-28.

13 Colige A, Sieron AL, Li SW, et al: Human Ehlers- Danlos type VIIC and bovine dermatosparaxis are caused by mutations in the procollagen I N-proteinase gene. Am J Hum Genet 1999;63:308-317.

14 Colige A, Nuytinck L, Hausser I, van Essen AJ, Thiry M, Herens C, Ades LC, Malfait F, De Paepe A, Franck P, Wolff G, Oosterwijk JC, Sillevis Smitt JH, Lapiere CM, Nusgens BV: Novel types of mutation responsible for the dermatosparactic type of Ehlers-Danlos syndrome (Type VIIC) and common polymorphisms in the ADAMTS2 gene. J Invest Dermatol 2004;123:656-663.

15 Wertelecki W, Smith LT, Byers P: Initial observations of human dermatosparaxis: Ehlers-Danlos syndrome type VIIC. J Pediatr 1992;121:558-564.

-16 Reardon W, Winter RM, Smith LT, Lake BD, Rossiter M, Baraitser M: The natural history of human dermatosparaxis (Ehlers-Danlos syndrome type VIIC). Clin Dysmorphol 1995;4:1-11.

17 Pasch MC, Sillevis Smitt JH, Veenhuizen L, Kuiters GRR, van der Wal AC, van Essen AJ: Een jongetje met dermotosparaxis (syndroom van Ehlers-Danlos type VII C). Ned Tijdschr Dermatol Venereol 2000;10:198-199.

18 Bar-Yosef O, Polak-Charcon S, Hoffman C, Feldman ZP, Frydman M, Kuint J: Multiple congenital skull fractures as a presentation of Ehlers-Danlos syndrome type VIIC. Am J Med Genet 2008;146A:30543057.

19 Giunta C, Superti-Furga A, Spranger S, Cole WG, Steinmann B: Ehlers-Danlos syndrome type VII: clinical features and molecular defects. J Bone Joint Surg Am 1999;81: 225-238.

20 De Coster PJ, Malfait F, Martens LC, De Paepe A: Unusual oral findings in dermatosparaxis (Ehlers-Danlos syndrome type VIIC). J Oral Pathol Med 2003;32:568-570.

21 Malfait F, De Coster P, Hausser I, van Essen AJ, Franck P, Colige A, Nusgens B, Martens L, De Paepe A: The natural history, including orofacial features of three patients with Ehlers-Danlos syndrome, dermatosparaxis type (EDS type VIIC). Am J Med Genet 2004;131:18-28.

-22 Petty EM, Seashore MR, Braverman IM, Spiesel SZ, Smith LT, Milstone LM: Dermatosparaxis in children. A case report and review of the newly recognized phenotype. Arch Dermatol 1993;129:1310-1315. 